\title{
A Design Method for Bolted Joints Fatigue under Transverse Vibration
}

\section{O正 橋村 真治（久留米高専）}

\author{
Shinji HASHIMURA, Kurume National College of Technology, Komorino 1-1-1, Kurume, Fukuoka
}

Key Words: Bolted Joint, Fatigue limit, Transverse Vibration, Prediction, Design Method

\section{1. 緒 言}

昨今, 軸直角方向振動を受けるねじ締結体の疲労破壊が 重大事故を引き起こすことは珍しくない，一方，軸直角方 向振動を受けるねじ締結体の疲労設計の方法は，未だ確立 されていない．著者らは，これまで軸直角方向振動を受け るボルト締結体の疲労破壊に関して研究を行い, 同じサイ ズや同じ強度区分のボルトであっても, 疲労破壊せずにボ ルト締結体に負荷することのできる軸直角方向加振力振幅 の上限值 (以下, 見かけの疲労強度) は, ボルト締結体のグ リップ長さ等の締結条件で異なることを明らかにした ${ }^{(1)}$.

本研究では，ボルト材の疲労強度からボルト締結体の見 かけの軸直角方向疲労強度を予測する方法を提案する。さ らに, 予測值と疲労試験結果と比較することで, 提案する 方法の有効性を検証する.

\section{2. 見かけの軸直角方向疲労強度の予測法}

ボルト締結体が, 図 1 のような軸直角方向力 $P_{t}$ を繰返し 受ける場合, ボルトは図 1 のように $\mathrm{S}$ 字状に変形し, 主と してボルトが雌ねじと齗合い始める第 1 ねじ谷底に疲労き 裂を生じる．本研究では， $P_{t}$ を受けて変形するボルトの変 形解析から，ボルトの第 1 ねじ谷底の公称応力 $\sigma_{t}$ と $P_{t}$ の 関係を求め，ボルト締結体の見かけの軸直角方向疲労限度 $\Delta P_{t w}$ を予測する方法を開発した。ここで，本研究では被締 結物間の摩擦力を便宜上無視するために, 図 1 のように, 被締結物間にリニアローラを設置して $P_{t}$ がすべてボルト 座面に作用するとした。

図 1 において, $\delta$ は軸直角方向の被締結物の変位であり, $\delta_{h}$ はボルト頭部の変位, $\delta_{s-s l i p}$ はボルトの荷重方向の変形量 である． $l_{g}$ はボルト締結体のグリップ長さ， $l_{e}$ はボルト締 結体のはめあい長さ， $l_{a}$ はボルト円頭部の長さ， $l_{b}$ はボル トの雄秝じが雌ねじと噛合い始めるまでの称じ部長さであ る遊び長さである。なお，ボルトの首下の点を点 $\mathrm{O}$ とし， ボルトの㸚じ部と円頭部の境界を点 $\mathrm{A}$, ボルトの第 1 ねじ 谷底部を点 $\mathrm{B}$ とする。図1において， $P_{t}$ が作用するとき， ボルトは雌斌じによって変形が拘束される。したがって, 点 $\mathrm{B}$ には曲げモーメント $M_{\mathrm{B}}$ が作用する。 この時, ボルト 頭部はボルト頭部と座面の弾性変形等によって $\varphi_{0}$ の傾き

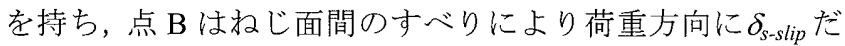
け移動するとともに，すべりとねじ山の弾性変形によって $\varphi_{\mathrm{B}}$ のたわみ角を有する。ここで, 座面のすべりを $\delta_{w-s l i p}$, ね じ部のすべりを $\delta_{s-s l i p}$, ボルトの荷重方向たわみ量を $\delta_{\text {def }}$ とす ると， $\delta$ はそれらの和として表される。ここで, $\delta_{w-s l i p}$ と $\delta_{s-s l i p}$ が $\delta_{\text {def }}$ に比べて小さいとき $\delta_{h}$ と $\delta_{\text {def }}$ はほぼ等しくなり, 図 1 における $\delta_{\text {def }}$ は，はり理論により次式で表わされる.

式(1)において， $E$ はボルト材のヤング率， $I_{a}$ は点 O-A

$$
\delta_{d e f}=\frac{P_{t} \cdot l_{a}^{3}}{3 \cdot E \cdot I_{a}}-\frac{M_{\mathrm{B}} \cdot l_{a}^{2}}{2 \cdot E \cdot I_{a}}+\frac{\left(P_{t} \cdot l_{b}\right) \cdot l_{a}^{2}}{2 \cdot E \cdot I_{a}}+\varphi_{\mathrm{o}} \cdot l_{a}+\left\{\frac{P_{t} \cdot l_{a}^{2}}{2 \cdot E \cdot I_{a}}-\frac{M_{\mathrm{B}} \cdot l_{a}}{E \cdot I_{a}}+\frac{\left(P_{t} \cdot l_{b}\right) \cdot l_{a}}{E \cdot I_{a}}+\varphi_{\mathrm{o}}\right\} \cdot l_{b}+\frac{P_{t} \cdot l_{b}{ }^{3}}{3 \cdot E \cdot I_{b}}-\frac{M_{\mathrm{B}} \cdot l_{b}{ }^{2}}{2 \cdot E \cdot I_{b}}
$$

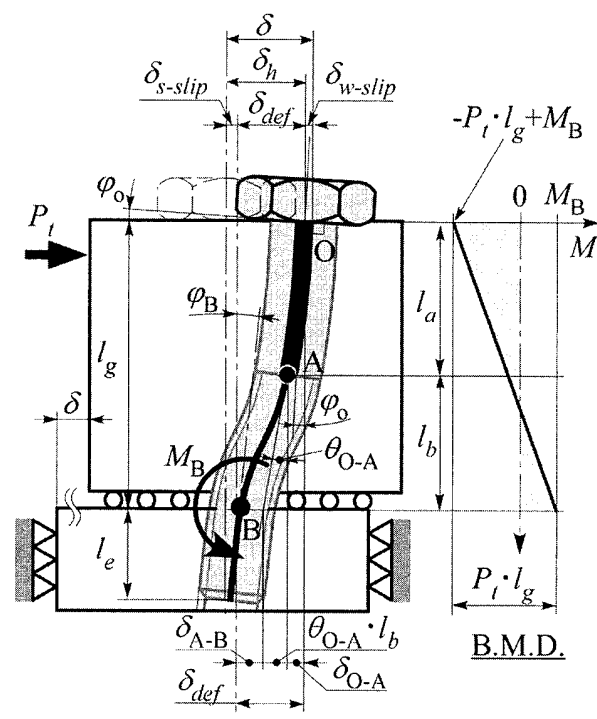

Fig.1 Schematic illustration of a bolt deformed 1 transverse force

間， $I_{b}$ は A-B 間のボルト谷底断面における断面二次モーメ ントである。 $\varphi_{\mathrm{o}}$ は, ボルト頭部の曲げ剛性 $k_{w 0}$ を比例定数 として， $\varphi_{0}=k_{w 0} \cdot P_{t}$ で表される。また，ボルトの B に作用 する曲げモーメント $M_{\mathrm{B}}$ は, 次式で表される.

$$
M_{\mathrm{B}}=C \cdot l_{g} \cdot P_{t}
$$

ここで式(2)における $C$ は，ボルト頭部とねじ部の拘束に 依存した係数であり,ボルトや被締結物の材質や締結条件, 潤滑条件によって $\varphi_{0}$ と $\varphi_{\mathrm{B}}$ に依存して変化する.図 1 の変形 状態において, $\varphi_{0}<\varphi_{\mathrm{B}}$ の場合は $C<0.5$ となり， $\varphi_{\mathrm{o}}>\varphi_{\mathrm{B}}$ の場合 は $C>0.5, \varphi_{0}=\varphi_{\mathrm{B}}$ の場合は $C=0.5$ となる。 ボル卜締結体が適 切な条件で使用されている場合, はめあいねじ部のバックラ ッシュにより，一般に $\varphi_{\mathrm{o}}<\varphi_{\mathrm{B}}$ となり $C<0.5$ になる.

式 (2) で示す $M_{\mathrm{B}}$ 寸なわち $C$ が既知となれば, 第 1 ねじ谷 底における公称曲げ応力 $\sigma_{t}$ は, ボルトのねじ谷底の直径を $d_{3}$ として次式で表され， $P_{t}$ と $\sigma_{t}$ の関係を明らかにすること ができる。

$$
\sigma_{t}=\frac{M_{\mathrm{B}}}{I_{b}} \cdot \frac{d_{3}}{2}
$$

本研究では, ボルト材の平滑材の疲労強度 $\sigma_{w 0}$ から, ボ ルトの軸直角方向疲労強度 $\sigma_{t w}$ を求め, 式 $(1) \sim(3)$ で示した $P_{t}$ と $\sigma_{t}$ の関係からボルト締結体の見かけの軸直角方向疲労 強度 $\Delta P_{t w} / 2$ を予測する方法を提案する。図 2 に, その予測 法のフローチャートを示し，以下に順に説明する。

1.まず，ボルト材の平滑材の疲労強度 $\sigma_{w 0}$ から，軸方向 


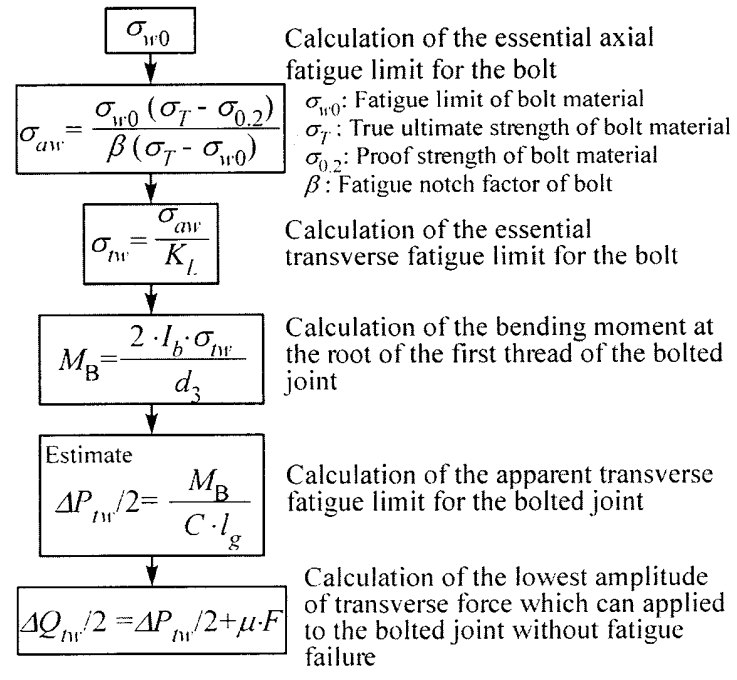

Fig.2 Flow chart of the proposed prediction method

疲労強度 $\sigma_{a w}$ を算出する ${ }^{(1)}$.

2 . 次に, 軸方向疲労強度 $\sigma_{a w}$ が軸方向疲労であるのに対 して, 軸直角方向疲労は繰返し曲げモーメントによって疲 労き裂を生じる。したがって， $\sigma_{a w}$ を荷重形態の修正係数 $K_{L}=0.92$ で除して, 軸直角方向疲労強度 $\sigma_{t w}$ を算出する.

3 . 式(3) 変形した式に $\sigma_{t w}$ を代入し, ボルトが疲労破壊 しない限界の点 $\mathrm{B}$ の曲げモーメント $M_{\mathrm{B}}$ を算出する。

4. 算出した $M_{\mathrm{B}}$ を, 式 (2) を変形した次式に代入し, ボル 卜締結体の見かけの疲労強度 $\Delta P_{t w} / 2$ を算出する。ここで $M_{\mathrm{B}}$ を求める際には，係数 $C$ の值が必要となる，そこで本研究 では， $M_{\mathrm{B}}$ の係数 $C$ は，実際に締結したボルト締結体に $P$ ， を静的に負荷し，その時の $P_{t}$ と $\delta_{d e f}$ の関係を，式(1) から得 られた式(4)に代入して決定した。

5.ここで $\Delta P_{t w} / 2$ は，図 1 で仮定したように，被締結物間 の摩擦力を無視した。しかし，実際にはボルト締結体の被 締結物閒には締付け力に依存した摩擦力が生じる。そこで 最後に, 締付け力 $F$ による被締結物間の摩擦力を $\Delta P_{t w} / 2$ に 加えて, 最終的なボル卜締結体の見かけの軸直角方向疲労 強度 $\Delta Q_{t w} / 2$ を予測する.ただし, なお本研究では $\Delta P_{t w} / 2$ を 予測し，予測した $\left(\Delta P_{t w} / 2\right)_{\text {pred }}$ を疲労試験で求めた $\left(\Delta P_{t w} / 2\right)_{\exp }$ と比較して, 本研究の方法の有効性を検証した.

\section{3. 見かけの疲労強度の予測法と検証}

図 3 に, 本研究で $\Delta P_{t w} / 2$ を予測した供試ボルトとそのボル 卜締結体の概略図を示す，ボルトは，す心゙て M10，強度区分 10.9 の市販の六角ボルトであり，その機械的性質は表 1 に示 す. 図 3 (a) は, 首下長さ $l=45 \mathrm{~mm}$, グリップ長さ $l_{g}=35 \mathrm{~mm}$, はめあい長さ $l_{e}=10 \mathrm{~mm}$ である. 図 $3(\mathrm{~b})$ は, $l=65 \mathrm{~mm}, l_{g}=55$ $\mathrm{mm}, l_{e}=10 \mathrm{~mm}$, 図 $3(\mathrm{c})$ は $l=80 \mathrm{~mm}, l_{g}=55 \mathrm{~mm}, l_{e}=25 \mathrm{~mm}$ で 女る。それぞれ，図 3 (a)の締結条件をCase I, 図 3 (b) を Case II, 図 3 (c) を Case III とした. 本研究では, これら 3 種類の ボルト締結体に対して，第 1 ねじ谷底に生じさせることの できる $M_{\mathrm{B}}$ の係数 $C$ を実験で算出し, ボル卜材の平滑材の 疲労強度 $\sigma_{w 0}$ から見かけの疲労強度 $\Delta P_{t w} / 2$ を導出した。

Table 1 Mechanical properties of test bolt ${ }^{(1)}$

\begin{tabular}{c|c|c|c|c}
\hline \hline$E$ & $\sigma_{0.2}$ & $\sigma_{T}$ & $\sigma_{w 0}$ & $\beta$ \\
\hline $206 \mathrm{GPa}$ & $940 \mathrm{MPa}$ & $1590 \mathrm{MPa}$ & $450 \mathrm{MPa}$ & 3.73 \\
\hline \hline
\end{tabular}

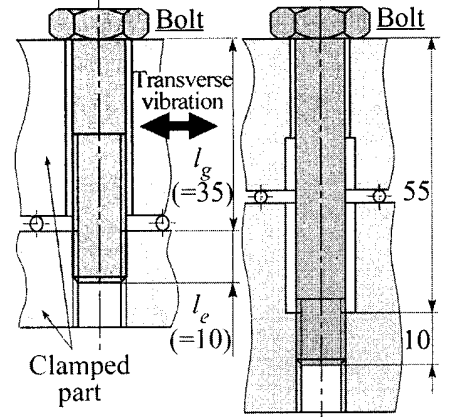

(a) Case I $(\mathrm{M} 10 \times 45)$

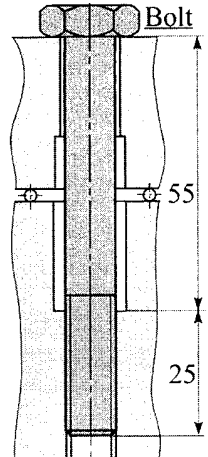

(c) Case III

$(\mathrm{M} 10 \times 80)$
Fig.3 Bolted joints for transverse fatigue test

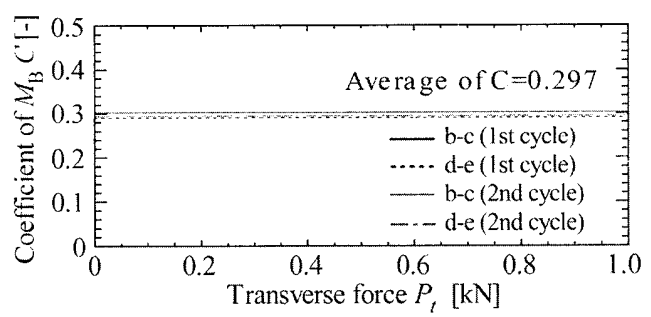

Fig.4 Behavior of coefficient $C$, calculated using a approximation

Table 2 Coefficient $C,\left(\Delta P_{t w} / 2\right)_{\text {pred }}$ and $\left(\Delta P_{t w} / 2\right)_{\exp }$

\begin{tabular}{c|c|c|c}
\hline \hline Case & Coefficient $C$ & $\left(\Delta P_{t w} / 2\right)_{\mathrm{pred}}$ & $\left(\Delta P_{t w} / 2\right)_{\exp }$ \\
\hline \hline Case I & 0.297 & $0.354 \mathrm{kN}$ & $0.30 \mathrm{kN}$ \\
\hline Case II & 0.399 & $0.168 \mathrm{kN}$ & $0.17 \mathrm{kN}$ \\
\hline Case III & 0.400 & $0.168 \mathrm{kN}$ & $0.16 \mathrm{kN}$ \\
\hline
\end{tabular}

$M_{\mathrm{B}}$ の係数 $C$ を導出する試験では, ボルトをスパナで $F_{i}$ $=15 \mathrm{kN}$ まで締付けた後, 軸直角方向力 $P_{t} \cong \pm 1.3 \mathrm{kN}$ を静的 に 2 サイクル負荷し，その際のボルト頭部の変位 $\delta_{h}$ を測定 した。なおボルト締結体の潤滑状態は，ねじ面および座面 ともに $\mathrm{MoS}_{2}$ グリースによる潤滑状態とした。

図 4 に，Case I における $P_{t}$ に対する $C$ の挙動を示す．本 研究では，ねじ面と座面でほとんどす心゙りがなく，ボルト の弾性変形のみで $\delta_{h}$ が生じる際の $\delta_{h}$ と $P_{t}$ の関係を式(4)に 代入して $P_{t}$ に対する $C$ の挙動を算出した. 図 4 を見ると, $C$ の值は極めて安定した值を取ることが分かる。このCを 用いて予測した $\left(\Delta P_{t w} / 2\right)_{\text {pred }}$ と, 先に行った疲労試験結果 $\left(\Delta P_{t w} / 2\right)_{\exp }$ を表 2 に示す ${ }^{(3)}$. 表 2 の結果から， $\left(\Delta P_{t w} / 2\right)_{\text {pred }}$ と $\left(\Delta P_{t w} / 2\right)_{\exp }$ はほぼ等しく, 本研究で提案した方法が $\Delta P_{t w} / 2$ を高い精度で予測できることが分かった。

\section{4. 結 言}

本研究では，ボルト材の公称応力から，軸直角方向振動 を受けるボルト締結体の見かけの疲労強度を予測する方法 を開発した。本方法で予测した見かけの疲労限度と疲労試 験結果を比較した結果，本研究で提案した予測法が見かけ の疲労強度を高精度で予測できることが分かった。

\section{参考文献}

（1）吉本 勇編著,"好し締結体設計のポイント", 日本梘格協会, (1997), pp.136-151.

（2）橋村 真治, 他 2 名, "ボル卜締結体におり斱直角方向疲労強度への締結条件の影響", 日本機械学会論文集 A 編, 76 巻, 771 号, pp.1436-1443, (2010).

$$
C=\frac{2 \cdot P_{t} \cdot\left\{\left(l_{a}{ }^{3}+3 \cdot l_{a}{ }^{2} \cdot l_{b}+3 \cdot l_{a} \cdot l_{b}{ }^{2}\right) \cdot I_{b}+l_{b}{ }^{3} \cdot I_{a}+3 \cdot E \cdot I_{a} \cdot I_{b} \cdot k_{w 0} \cdot l_{g}\right\}}{3 \cdot l_{g} \cdot\left\{\left(l_{a}{ }^{2}+2 l_{a} \cdot l_{b}\right) I_{b}+l_{b}{ }^{2} \cdot I_{a}\right\} P_{t}}-\frac{6 \cdot E \cdot I_{a} \cdot I_{b} \cdot \delta_{d e f}}{3 \cdot l_{g} \cdot\left\{\left(l_{a}{ }^{2}+2 l_{a} \cdot l_{b}\right) I_{b}+l_{b}{ }^{2} \cdot I_{a}\right\} \cdot P_{t}}
$$

